\title{
Analysis of Student Errors in Solving Analytic Geometry Questions During the Covid Pandemic 19
}

\author{
Titin Masfingatin ${ }^{1}$, Restu Lusiana ${ }^{2}$, Swasti Maharani $^{3}$ \\ \{titin.mathedu@unipma.ac.id ${ }^{1}$, restu.mathedu@unipma.ac.id ${ }^{2}$, swasti.mathedu@unipma.ac.id ${ }^{3}$ \} \\ Mathematics Education Program, Universitas PGRI Madiun, Indonesia ${ }^{1,2,3}$
}

\begin{abstract}
The Covid-19 pandemic has a very significant impact on the world of education in higher education. Online learning is applied as a solution for implementing the learning process. This study aimed to analyze and describe the mistakes made by students in solving analytic geometry problems. The analysis was conducted based on Newman's theory. This research is descriptive qualitative. The study was conducted at the Universitas PGRI Madiun. The research subjects were 63 students of semester IV, the Mathematics Education Program. Data analysis includes data reduction, data presentation, and concluding. The results of the research are the most mistakes made by students are comprehension errors (74.60\%), transformation errors (20.63\%), and encoding errors $(3.17 \%)$. In this study, students did not make reading and processing errors. The mistakes made by students indicate the low understanding of students in analytic geometry online courses when Covid-19 pandemic.
\end{abstract}

Keywords: Error analysis, analytic geometry, pandemic covid 19.

\section{Introduction}

Mathematics is a learning material that plays an important role in the world of education. Simple mathematical principles to high-level mathematics can help someone solve problems faced in everyday life. In studying mathematics, the ability to think mathematically, systematically, logically, critically, and creatively is needed [1],[2]. So, it can be said that mathematics is a science which is the basis for the development of science and technology, because it can be widely applied in various fields. Mathematics has several branches, one of which is geometry.

Students of the mathematics education study program in Universitas PGRI Madiun are required to take courses in field analyte geometry in accordance with the established curriculum. In general, field analyte geometry is a combination of algebra and abstract geometry. By connecting mathematical equations algebraically with geometrical positions, a more systematic and firm method of solving geometric problems is obtained. Mathematics education students are required to be able to master basic competencies in every subject, especially analytic geometry, because they are prepared to become professional teachers. The mastery of students' basic competencies in the field analyte geometry course can be obtained through a learning process prepared by the lecturer. The learning process, which is usually done face-to-face in class, is now no longer conducive to doing. This is because the Covid-19 pandemic is happening in various countries, including Indonesia. 
The covid-19 pandemic has changed the paradigm of direct learning with the online system [2]. Changes in the learning paradigm during the Covid-19 pandemic are one of the government policies in the field of education as an effort to prevent the spread of the covid-19 virus that is too fast[3]. The spread of the covid-19 virus is too fast because a cure has not yet been found [4]. This becomes a new challenge for lecturers to be able to present an effective online learning process for students. Various attempts have been made to optimize the online learning process.

However, based on the results of the questionnaire data analysis, it shows that there are several obstacles faced by students during the online learning process of analyte geometry. The two main obstacles that arise are the unstable internet connection of students due to different regional conditions and the lack of students' ability to accept new knowledge given by online lecturers. This condition has an impact on the emergence of learning difficulties experienced by students. Learning difficulties are marked by certain obstacles to achieving learning outcomes [5]. Learning difficulties are not related to student intelligence, but are related to student difficulties in mastering learning skills [6]. Learning difficulties usually arise because students have not received complete knowledge [7].

In the analyte geometry course, learning difficulties experienced by students occur because students face complex processes in solving problems related to understanding concepts and formulas. This results in students making mistakes in solving the given math problems. The occurrence of errors when solving mathematical problems is very possible because there are errors when constructing concepts [8]. These errors need to be identified immediately through analysis activities so that they do not have an impact on allied subjects in the following semester. Error analysis is an investigation of a form of deviation or error from students' written answers [9]. Therefore, student errors in solving field analyte geometry problems can be analyzed from errors originating from student answer sheets. The analysis of errors in this study is based on Newman's theory, which consists of reading errors, misunderstanding, transformation, processes and final answers.

Previous research on error analysis in solving geometric problems by [10] has been carried out. The research was conducted before the Covid-19 pandemic, which applies face-to-face learning. During the Covid-19 pandemic, learning was carried out online. Research by [11][13] states that online learning has many weaknesses that impact students' ability to the material being studied. Therefore, we want to analyze student errors in solving analyte geometry problems in online learning during the Covid-19 period. This study aims to obtain information about the errors experienced by students in solving analyte geometry problems, which can be used to determine the weaknesses of learning online in terms of student abilities. The results of this study can later be used as a reference and material for consideration in designing online learning that is suitable for analyte geometry courses. Based on the results of research on error analysis, in the future lecturers can design a learning process that can help overcome student difficulties [14].

\section{Methods}

This research uses a qualitative approach with a case study model. The research was conducted at the PGRI Madiun University in the fourth semester students of the Mathematics Education Study Program who are currently taking the Analytical Geometry course. The research subjects consisted of 63 students. Determination of the subject based on the type of error committed. The main instrument in this study was the researcher, while the auxiliary 
instruments were in the form of a circle equation problem-solving test and an interview guide. Data analysis techniques include data reduction, data presentation and drawing conclusions.

\section{Result and Discussion}

Error analysis is an activity of analyzing errors made by students in solving analyte geometry problems. The research subjects were 63 fourth semester students of the Mathematics Education Study Program of the PGRI Madiun University. Table 1. is the results of the error analysis on solving student analyte geometry problems.

Table 1. The results of the error analysis on solving student analytic geometry problems.

\begin{tabular}{cll}
\hline No & \multicolumn{1}{c}{ Type of Error } & \multicolumn{1}{c}{ Percentage } \\
\hline 1. & Reading error & $0 \%$ \\
2. & Comprehension Error & $74.60 \%$ \\
3. & Transformation error & $20.63 \%$ \\
4. & Process skill error & $0 \%$ \\
5. & Encoding & $3.17 \%$ \\
\hline
\end{tabular}

Based on the data in Table 1. It shows that the errors made by students are comprehension errors of $74.60 \%$, transformation errors, amounting to $20.63 \%$ and the final answer errors of $3.17 \%$. In this study, students did not make reading errors and processing errors. Students do not experience errors reading questions. This strengthens the results of research [15], [16]. In general students do not experience errors in reading questions. Although in this study each subject worked online, based on the results of the answers all the information showed that students did not experience reading errors. In research, students also did not experience process errors. Process skill error is a student's mistake in choosing rules/procedures or students already using correct procedures/rules, but errors occur in the calculation or computation [16]. Students do not make mistakes in choosing or using problem solving procedures. Students also do not make mistakes in the counting process. This is because during the Covid-19 pandemic students studied online. Students work on the questions independently. This strengthens the results of research [17] that online learning can increase student motivation and learning independence.

Comprehension error is the type of error in which students have read the problem well, but do not understand the meaning of the question (eg cannot identify known and asked of the problem) [16]. Fig 1. is an example of misunderstanding by students.

Karena lingkaran berpurat pada rumbu $x$, maka $B=0$
subititusi $B-0$ Ke perramaan 2
$\Rightarrow-A+\frac{1}{2}(0)=0$
$-A=0$
$A=0$


Fig. 1. The example of understanding error by students.

Fig. 1. students write that the circle is centered on the X-axis. In the problem it is clearly stated that the center of the circle is on the line. This shows that students do not understand the questions. Students experience errors in determining known information. Students have an understanding that a circle that is tangent to the $\mathrm{X}$-axis is the same as a circle whose center is on the $\mathrm{X}$-axis. students are able to read the questions correctly, but unable to determine the information they know correctly. Misunderstanding in this study dominates the mistakes made by students. Misunderstanding often occurs in the problem solving process. This supports the results of the research [15], [16], [18] that misunderstanding always appears in solving student problems. Students may have mastered the material being studied, but have not been able to implement it in solving the problems at hand. This strengthens the research [18]. This misunderstanding occurs because learning is carried out online so that students cannot face-toface with the lecturer. This is in accordance with the opinion [11], [12], namely the weakness of online learning, namely students have difficulty understanding the subject matter which results in student understanding of the material less than optimal.

The application of online learning in analyte geometry courses has been for lecturers to upload material online in university e-learning. Students can access the material and study it independently. Then the lecturer provides feedback in the form of questions for students to work on and the results are uploaded to e-learning. During learning, students independently study the material, search for sources on the internet or discuss with peers. However, discussions with lecturers have not been carried out, so students are more likely to look for sources on the internet and have discussions with other friends. The results of the study [13] show that students experience difficulties in learning mathematics online. This allows students to have difficulty understanding the material being studied.

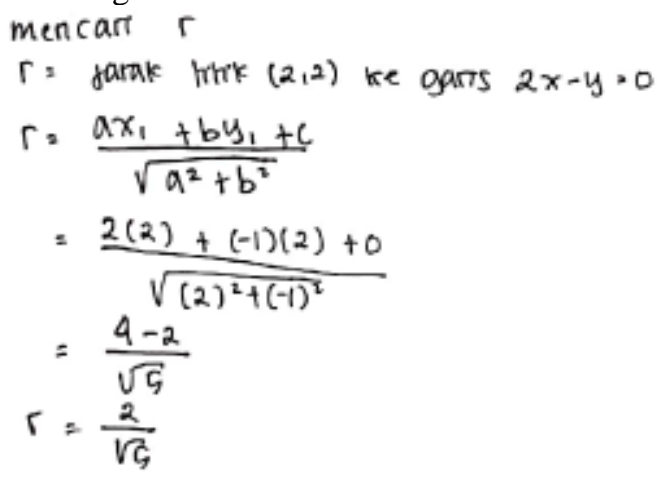

Fig 2: Examples of transformation errors

Subjects experiencing errors in transforming known information into mathematical equations. This is shown from the written statement, namely. This means that the radius of the circle is equal to the distance of the point $(2,2)$ to the line. Thus students experience errors in transforming problems.

Transformation errors, namely errors caused by the failure of students to transform important information into mathematical equations. Transformation errors are caused by errors in understanding. The results of the study [10] show that students experience transformation errors in geometry due to poor understanding of the material. 


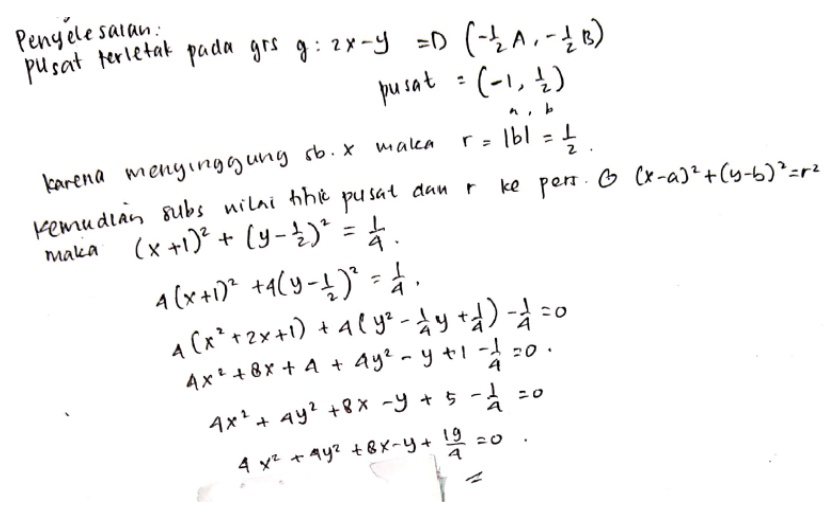

Fig 3: The Example of encoding errors

Encoding error that students make is when the subject determines the center of the circle. The subject of writing an equation for the center of the circle is, namely, the equation for the center of the circle for the general equation for the circle. The subject writes that the center of the circle is. This means that the subject made a mistake in determining the center of the circle. The center of the circle should still be in the form of a variable whose value is unknown. Furthermore, the subject substitutes the center point value and the radius value into the standard equation of circumference, namely. The choice of this equation is incorrect. This is because the center of the circle should be in the form of variable A or B, which of course does not fit the standard circle equation. Subjects cannot write solutions according to the completion procedure used. This error is called an encoding error. The results of this study contradict the results of research [10] that students do not make encoding errors in solving geometric problems. This research by [10] was carried out before the Covid-19 pandemic. Before the Covid-19 pandemic, learning was carried out face-to-face. This allows students to interact directly with lecturers or fellow students. Learning using online results in students being less maximal in understanding the material being studied [11], [12].

This study informed the students of misunderstanding, transformation, and encoding in solving analytic geometry problems. Learning that took place during the Covid-19 pandemic was online, using university e-learning. The learning design that has been implemented is that the lecturer uploads material in the form of powerpoints in e-learning. Students download the material and then study it independently. It allows students to experience errors in understanding the material. The lecturer gives questions related to the material being studied, and then the students upload the answers. This kind of learning design can cause difficulties for students, which results in students' understanding of the material less than optimal. The research result which conducting by [13], shows that in online learning, students do not accept the concept directly between teachers and students. When finding difficult questions, students tend to negotiate by accepting the situation or surrendering and being silent because of students' lack of understanding of the material studied through e-learning. In other side, [12], [19] stated that online mathematics learning is often ineffective due to poor internet networks, which impact on students' low understanding of the material. The study conducting by [20] One of the causes of difficulties experienced by students in online learning is the lecturers' unpreparedness, which includes inadequate explanations, the limited form of the material provided, and the limited applications used by lecturers in online learning. Analysis of student errors includes errors in understanding, transformation, and encoding in solving analyte geometry problems in online learning during 
the Covid-19 pandemic. It is possible due to learning that takes place without face-to-face. Students learn the material independently in e-learning. The next cause is the lecturer's limited form of material and the limited application used by the lecturer. Besides, it is also indicated that there are internet network problems. For the next online learning, it is recommended that lecturers be more creative in designing learning by utilizing supporting applications, such as learning videos, google classroom platforms, zoom cloud meetings, and so on to make learning more effective [17].

\section{Conclusions and Suggestions}

The results of this study were errors made by students in solving analyte geometry problems including understanding errors $(74.60 \%)$, transformation errors $(20.63 \%)$ and encoding errors $(3.17 \%)$. Students do not make reading errors and processing errors. This error was caused by the lack of students' ability to understand field analyte geometry material in online learning during the Covid-19 pandemic. Online learning designs during Covid-19 which need to be reviewed and innovated so that students can more easily absorb learning material.

Suggestions that can be implemented in relation to the results of this study are to immediately improve the learning design in analyte geometry courses. Presentation of the material was also more innovated so that students could more easily understand the analyte geometry material.

Acknowledgments. The author is grateful to students of the mathematics education study program who have been willing to be the subject of this research.

\section{References}

[1] A. Anugrahana, "Tinjauan Deskriptif Penerapan Higher Order Thinking dan Problem-Based Learning Pada Mata Kuliah Geometri Berdasarkan Kemampuan Matematika Mahasiswa,” Sch. J. Pendidik. dan Kebud., vol. 8, no. 2, pp. 142-156, 2018.

[2] J. Reyna, "Twelve Tips for COVID-19 friendly learning design in medical education," MedEdPublish, vol. 9, no. 1, pp. 1-16, 2020.

[3] M. B. N. Wajdi, Iwan Kuswandi, Umar Al Faruq, Z. Zulhijra, K. Khairudin, and K. Khoiriyah, "Education Policy Overcome Coronavirus, A Study of Indonesians," EDUTEC J. Educ. Technol., vol. 3, no. 2, pp. 96-106, 2020.

[4] N. Karki, “' Solidarity Trial ': A Feeling of Trust Towards COVID-19 Treatments," vol. 8, no. 1, pp. $0-1,2020$.

[5] W. Wantika and S. P. Nasution, "Analisis Kesulitan Belajar dalam Memahami Kecemasan Peserta Didik pada Pembelajaran Matematika,” Desimal J. Mat., vol. 2, no. 1, pp. 49-57, 2019.

[6] N. Wasito and F. A. Kurniawan, "Analisis Penyebab Kesulitan Belajar Mahasiswa dalam Pembelajaran Konstruktivistik Mata Kuliah Aljabar Linier,” J. Pendidik. Mat. Indones., vol. 3, no. 2, pp. 47-51, 2018.

[7] M. H. Albadawi, H. Zulfa, and S. Sumani, "Analisis Kesulitan Siswa Kelas X SMAN I Rejotangan pada Materi Bentuk Akar dan Solusi yang Ditawarkan,” J. Tadris Mat., vol. 1, no. 1, pp. 77-96, 2018.

[8] L. M. Lestyanto, S. H. Nasution, E. Tejo, D. Cahyowati, M. S. Kahfi, and U. N. Malang, "Kesalahan konstruksi konsep mahasiswa pada materi himpunan dan defragmentasi struktur berpikirnya," J. Rev. Pembelajaran Mat., vol. 4, no. 2, pp. 128-142, 2019.

[9] I. R. Arvianto, "Kesalahan Mahasiswa dalam Menyelesaikan Soal Integral Berdasarkan Gaya Kognitif pada Mata Kuliah Matematika Informatika,” JMPM J. Mat. dan Pendidik. Mat., vol. 2, no. 1, p. 36, 2017. 
[10] K. F. Zamzam and F. A. Patricia, "Error Analysis of Newman to Solve the Geometry Problem in Terms of Cognitive Style,” Adv. Soc. Sci. Educ. Humanit. Res., vol. 160, pp. 24-27, 2018.

[11] S. Loviana and W. N. Baskara, "Dampak Pandemi Covid-19 Pada Kesiapan Pembelajaran Tadris Matematika IAIN Metro Lampung," Epsilon, vol. 1, no. 2, pp. 61-70, 2020.

[12] D. Novita and A. R. Hutasuhut, "Plus Minus Penggunaan Aplikasi-Aplikasi Pembelajaran Daring Selama Pandemi Covid-19," Unimed Medan, no. June, pp. 1-11, 2020.

[13] Y. P. Utami, D. Alan, and D. Cahyono, "Study At Home: Analisis Kesulitan Belajar Matematika Pada Proses Pembelajaran Daring," J. Ilm. Mat. Realis., vol. 1, no. 1, pp. 20-26, 2020.

[14] T. Listiani, K. P. S. Dirgantoro, M. J. Saragih, and K. P. Tamba, "Analisis Kesalahan Mahasiswa Pendidikan Matematika Dalam Menyelesaikan Soal Geometri Pada Topik Bangun Ruang [Error Analysis of Students in the Mathematics Department in Solving Geometry Problems on the Topic of Solid Figures]," JOHME J. Holist. Math. Educ., vol. 3, no. 1, p. 44, 2019.

[15] N. S. A. Alhasora, M. S. Abu, and A. H. Abdullah, "Newman Error Analysis on Evaluating and Creating Thinking Skill,” Man India, vol. 97, no. 19, pp. 413-427, 2017.

[16] H. N. Fitriani, T. Turmudi, and S. Prabawanto, "Analysis Of Students Error in Mathematical Problem Solving Based on Newman' S Error Analysis,” Int. Conf. Math. Sci. Educ., vol. 3, pp. 791-796, 2018.

[17] A. Warmi et al., "Motivasi dan Kemandirian Belajar Siswa Pada Mata Pelajaran Matematika di Masa Pandemi Covid-19 (Studi Pada Siswa Kelas VII SMPN 3 Karawang Tahun Pelajaran 2019-2020)," J. Educ. Dev., vol. 8, no. 3, pp. 197-202, 2020.

[18] N. A. Abdullah and M. S. Mirza, "Evaluating pre-service teaching practice for online and distance education students in Pakistan," Int. Rev. Res. Open Distance Learn., vol. 21, no. 2, pp. 81-97, 2020.

[19] B. Kusumaningrum and Z. Wijayanto, "Apakah Pembelajaran Matematika Secara Daring Efektif? ( Studi Kasus pada Pembelajaran Selama Masa Pandemi,” Kreano , J. Mat. Kreat., vol. 11, no. 2, pp. 139-146, 2020.

[20] M. F. Annur and H. Hermansyah, "Analisis Kesulitan Mahasiswa Pendidikan Matematika dalam Pembelajaran Daring Pada Masa Pandemi Covid-19," Paedagoria J. Kajian, Penelit. dan Pengemb. Kependidikan, vol. 11, no. 2, pp. 195-201, 2020. 